\title{
U⿱宀⿻三丨口
}

\section{An historical tract in Irish relating to the confederate wars in Ireland}

Smith [Mac Gabhann], P. P. (2017). An historical tract in Irish relating to the confederate wars in Ireland. Studia Hibernica, 43, 25-52. https://doi.org/10.3828/sh.2017.2

Link to publication record in Ulster University Research Portal

\section{Published in:}

Studia Hibernica

Publication Status:

Published (in print/issue): 30/09/2017

DOI:

10.3828/sh.2017.2

\section{Document Version}

Author Accepted version

\section{General rights}

Copyright for the publications made accessible via Ulster University's Research Portal is retained by the author(s) and / or other copyright owners and it is a condition of accessing these publications that users recognise and abide by the legal requirements associated with these rights.

\section{Take down policy}

The Research Portal is Ulster University's institutional repository that provides access to Ulster's research outputs. Every effort has been made to ensure that content in the Research Portal does not infringe any person's rights, or applicable UK laws. If you discover content in the Research Portal that you believe breaches copyright or violates any law, please contact pure-support@ulster.ac.uk. 


\title{
An historical tract in Irish relating to the confederate wars in Ireland
}

\author{
PETER SMITH \\ (Ulster University)
}

\begin{abstract}
The hitherto unpublished historical tract which is presented here was written by a Fermanagh scholar called Conchabhar Ó Luinín during the period c. 1652-1700. It affords us a unique insight into Irish feelings about the Confederate Wars in Ireland. Ó Luinín shares with us his personal reflections on the campaign in the first section of the tract before proceeding to list in the subsequent sections the battles fought and the names of the eminent Irish soldiers killed in combat. The text has survived in fragmentary form among the O'Conor Papers and is preserved in Dublin, Royal Irish Academy B i la (Catalogue Number 1078).
\end{abstract}

\section{Introduction}

The manuscript

Preserved in Royal Irish Academy manuscript B i 1a (Catalogue Number 1078) ${ }^{1}$ is a fragmentary historical tract that appears to have been written within about fifty years of the end of the Confederate Wars in Ireland. ${ }^{2}$ The tract forms part of a miscellany of materials that has been assembled under the title: 'MS. Fragments, O'Conor Papers, etc.' The catalogue description states:

Mainly $18^{\text {th }}$ cent. These fragmentary sections of MSS have been wrapped separately, and numbered in pencil by the present cataloguer. Nos. 3-7, though not all by the same hand, were originally part of the same MS. Nos. 4-6 are in the handwriting of Conchubhar Úa Luinín, see signature in $4 .^{3}$

\footnotetext{
${ }^{1}$ E. FitzPatrick, Catalogue of Irish manuscripts in the Royal Irish Academy, Dublin, Fasciculus 24 (Dublin, 1940), 3016-19.

${ }^{2}$ J. Kenyon, J. Ohlmeyer (eds), The civil wars (Oxford, 1998); T. Royle, Civil war: the wars of the three kingdoms 1638-1660 (London, 2004); P. Lenihan, Confederate Catholics at war (Cork, 2001); G. A. Hayes-McCoy, Irish battles (Belfast, 1990); J. Scott-Wheeler, Cromwell in Ireland (Dublin, 1999); Micheál Ó Siochrú, God's executioner: Oliver Cromwell and the conquest of Ireland (London, 2009); D. Plant, 'The Confederate War 1641-1652'. See http://bcw-project.org/military/ confederate-war/.

${ }^{3}$ FitzPatrick, Catalogue of Irish manuscripts in the RIA, 3016.
} 
The section in which our historical tract has survived has been assigned the title 'Section 4' by the cataloguer. It comprises seventeen folios the dimensions of which are circa $8 \times 6$ inches. A portion of $A$ eolcha Erenn airde occupies the space between the colophon on $\mathrm{f} .4 \mathrm{v}$ and $\mathrm{f}$. $6 \mathrm{r}^{4}{ }^{4}$ The historical tract has been preserved on the folios that run from f. $6 \mathrm{v}$ to f. 10r [recte 9r]. Unfortunately, damage to the manuscript, particularly at the edges, has resulted in the loss of parts of the text. For example, the bottom portion of f. $9 \mathrm{v}$ has been so badly damaged that most or all of lines 23-26 have been lost to us.

\section{Subject matter}

The text is divided into three sections. The beginning of each section is indicated by the use of uppercase letters in red ink. Sub-sections are denoted by the use of uppercase letters. Section 1 begins at f. 6v1 with the words MÍLE SÉ CHÉUD DHÁ FHITHCHEAD AGUS and ends at f. 6v15 with go hiomlán. This section contains the scribe's thoughts on the implications of the Confederate campaign from an Irish perspective. Ó Luinín's view was that the campaign was perniciousmibheartach (6v4).

Section 2, which enumerates the battles fought in Leinster, Munster and Ulster, begins at $6 \mathrm{v} 16$ with the words Ó THÚS. It ends at the bottom of a folio upon which the number ' 9 ' has been written in pencil in the top left corner. Beside that is a circled 4, an indication that this folio belongs to section 4 of MS B i la. The final lines of the folio have been lost as a consequence of damage to the manuscript. On the lower margin of folio 9r has been inserted the number '[38]'.

The preceding folio, which bears the numbers ' 8 (4)' in pencil in the top left corner of the recto and ' $8 \mathrm{v} \mathrm{(4)'} \mathrm{on} \mathrm{the} \mathrm{top} \mathrm{right} \mathrm{corner} \mathrm{of} \mathrm{the} \mathrm{verso} \mathrm{has} \mathrm{been}$ misplaced and wrongly inserted into our historical tract. It is a part of the chronicle (AD 1106-1156) which runs from fols. ' 1 [recto] to $4 \mathrm{v}$ [erso]'. For example, line 5 of f. '8 (4)' begins: SluaighEdh la Muirchertach mac Neill ui Lachloinn and records that Diarmuid Mac Murchadha, king of Leinster submitted to Muirchertach. The passage corresponds to AFM 1157.10: Slóighedh lá Muirchertach, mac Néill Ui Lochlainn co t-Tuaisceart Ereann imme h-i Laighnibh go t-tart rí Laighen, Diarmaid Mac Murchadha, géill dó ('An army was led by Muircheartach, son of Niall Ua Lochlainn, accompanied by the people of the north of Ireland, into Leinster; and the King of Leinster, Mac Murchadha, gave hostages'). ${ }^{5}$ The insertion of this folio in the incorrect place has disrupted the sequence of the foliation. Folio ' 9 [recto]' and ' $9 \mathrm{v}$ ' should therefore be counted as folio 8 recto and 8 verso respectively. My conclusions regarding the sequence of the folios are reflected in the following table:

${ }^{4}$ P. J. Smith, 'A eolcha Érenn airde: a medieval poem on the pre-Christian kings of Ireland', Zeitschrift für Celtische Philologie 60 (2013), 175-238.

${ }^{5}$ Text and translation from J. O'Donovan's first edition of Annála Rioghachta Éireann: Annals of the Kingdom of Ireland by the Four Masters, 7 vols (Dublin, 1848-1851) on celt.ucc.ie (accessed 1 Aug. 2017). 


\begin{tabular}{lll}
\hline $\begin{array}{l}\text { Cataloguer's number, } \\
\text { top of page }\end{array}$ & $\begin{array}{l}\text { Cataloguer's number, } \\
\text { bottom of page }\end{array}$ & This edition \\
\hline $6 \mathrm{v}(4)$ & Blank & $6 \mathrm{v}$ \\
$7(4)$ & Blank & $7 \mathrm{r}$ \\
$7 \mathrm{v}(4)$ & Blank & $7 \mathrm{v}$ \\
$8(4)$ & Blank & Omitted \\
$8 \mathrm{v}(4)$ & Blank & Omitted \\
$9(4)$ & {$[38]$} & $9(8) \mathrm{r}$ \\
$9 \mathrm{v}(4)$ & Blank & $9(8) \mathrm{v}$ \\
$(4)$ & {$[39]$} & $10(9) \mathrm{r}$ \\
\hline
\end{tabular}

The Ui Luinin family and Irish scholarship

Conchabhar Ó Luinín belonged to the Uí Luinín family who furnished the Mág Uidhir (Maguire) family of Fermanagh with professional historians for several centuries. ${ }^{6}$ Fr Livingstone noted the link between the Uí Luinín in their capacity as an airchinneach family and the church of Doire Mhaoláin (Derryvullen) near Irvinestown. ${ }^{7}$ Their name was anglicised as Lunny in Fermanagh, ${ }^{8}$ and their chief residence was located in the townland of Arda, in the parish of Derryvullan and the Islands, and the barony of Tirkennedy. The full form of the townland name was Arda Mhuintir Luinín. ${ }^{9}$

\section{Other extant works by Conchabhar Ó Luinin}

Dublin, National Library of Ireland MS G 129, a paper manuscript of dimensions $19.8 \times 15 \mathrm{cms}$, contains ninety-two pages. ${ }^{10}$ Pages 67 and 91 give the name of the scribe as Conchabhar Ó Luinin and the date of writing as 1676. This miscellany

${ }^{6}$ For a survey of the work of the Fermanagh scribes, see C. Ó Baoill, 'Scríobhaithe agus saothrú an léinn i dtuaisceart na hÉireann ó c. 1300 i leith: tús taighde', Léann 1 (2007), 77-91, at 81-82.

${ }^{7}$ P. Livingstone, The Fermanagh story: a documented history of the county of Fermanagh from the earliest times to the present day (Enniskillen, 1969), 41.

${ }^{8}$ Livingstone believed that the Uí Luinín had their origins in the Muintir Luinigh who together with the Uí Ghormlaigh comprised the Cineál Moain. In the early Middle Ages, the Cineál Moain inhabited Mag nÍtha in the parish of Cluain Laoigh/Clonleigh, barony of Raphoe on the west bank of the Foyle river system. They were later pushed eastwards, however, into the barony of Strabane as a consequence of the expansion of the Clann Dálaigh: see The Fermanagh story, 431. See 'Mag nItha and Cenél Conaill' in B. Lacey, Cenél Conaill and the Donegal Kingdoms AD 500-800 (Dublin, 2006), 131-43.

${ }^{9}$ See for example AU 1540.12: Plaig do beth a $n$-Arda Muinntire Luinin \& Neime O Luinin d'eg \& a bean \& clann ('Plague in Arda Muintir Luinín and Neime Ó Luinín died together with his wife and children'): see http://www.ucc.ie/celt/published/G100001C/index.html.

${ }^{10}$ N. Ní Shéaghdha, Catalogue of Irish manuscripts in the National Library of Ireland, Fasciculus 4, MSS G 115-160 (Dublin, 1977), 46-47. 
of poetry features Iomarbháigh na bhFileadh ('The Contention of the Poets'). ${ }^{11}$ In 1693 Conchabhar wrote the manuscript which is now preserved as Dublin, Royal Irish Academy, manuscript A iii 2 (735). ${ }^{12}$

National Library of Ireland G 448 is a paper manuscript of $19 \times 15 \mathrm{cms}^{13} \mathrm{It}$ contains 124 pages. The manuscript was written by Conchubhar Ua Lunin/Cornelius Lunin in 1711-12. The material comprises a miscellany of prose and poetry. Most notable among the prose texts are the early modern romantic tales Imtheacht agus Bás Cearbhaill agus Farblaidhe ('The Departure and Death of Cearbhall and Farbhlaidh'; pp. 1-25), and Ceasacht Ingine Guile ('The Complaint of the Daughter of Goll'; pp. 52-67); a modern version of the Old Irish Ulster Cycle tale Scéla Muicce Meic Da Thó ('The story of Mac Da Thó's pig'; pp. 67-89) and a modern version of the King Cycle tale, 'The Death of Conn Cétchathach' (pp. 90-104). ${ }^{14}$ Among the poems is Mór do-níd daoine dhiobh féin (p. 109) by Fear Feasa Ó’n Cháinte (fl. 1600). ${ }^{15}$

Dublin, National Library of Ireland G 459 is a paper manuscript of $20 \times 14 \mathrm{cms},{ }^{16}$ containing sixty-eight pages. ${ }^{17}$ The date 1676 is given in the upper-right corner of page 31. Under the date is written aon do leabhraibh Stiabhna RÍghis arna sgriobhadh leis fein san mbliadhuin 1719 ('One of the books of Stephen Rice having been written by himself in the year 1719'). The cataloguer declares that the 'hand throughout the manuscript is, nevertheless, Ó Luinín's'.18 Conchabhar Ó Luinín's name and the date 1676 appear on page 65 as Conchabhar o Luinín 1676. The text which has been preserved in the manuscript is Eachtra Mhacaoimh-an-Iolair, which is also known by the variant title, Eachtra Mhic an Iolair ('The Adventure-Tale of the Eagle's Youth/ Son'). ${ }^{19}$ It finishes with the words $A g$ sin duit a Thordhealbhaigh Ui Gábhan ('That is for you, o Toirrdhealbhach Ó Gabhan' (recte ‘Ó Gabhann’?).

Dublin, Royal Irish Academy, MS A iii 3 (\# 735), a paper manuscript of 121/2 $\times 7 \frac{1}{2}$ inches, was also written by Conchabhar Ó Luinín in Muintir Cionaith in

${ }^{11}$ L. McKenna (ed. \& trans.), The contention of the bards, Parts 1-2, Irish Texts Society 20-21 (London, 1918-20); Joep Leerssen, The contention of the bards and its place in Irish political and literary history (London, 1994).

${ }^{12}$ See G. Murphy and W. Wulff, Catalogue of Irish manuscripts in the Royal Irish Academy, Fasciculus 18 (Dublin, 1936), 2236-37.

${ }^{13}$ This manuscript and G 459 were bought from Edward O'Reilly's collection by Lord Rossmore for the Library of Rossmore House, Co. Monaghan.

${ }^{14} \mathrm{C}$. Breatnach, Patronage, politics and prose: Ceasacht ingine Guile, Sgéala muice Meic Dhá Thó, Oidheadh Chuinn Chéadchathaigh, Maynooth Monographs 5 (Maynooth, 1996).

${ }^{15}$ See S. H. O'Grady, Catalogue of Irish manuscripts in the British Library [Formerly, the British Museum], 3 vols (London, 1926), i, 555.

${ }^{16}$ N. Ní Shéaghdha, Catalogue of Irish manuscripts in the National Library of Ireland, Fasciculus 10, MSS G 434-G 500 (Dublin, 1987), 52.

${ }^{17}$ For the digital image of the manuscript, see https://www.isos.dias.ie/resources/image.html.

${ }^{18}$ N. Ní Shéaghdha, Catalogue of Irish manuscripts in the NLI, Fasciculus 10, MSS G 434-G 500 (Dublin, 1987), 52.

${ }^{19}$ R. A. S. Macalister (ed. and trans.), Two Irish arthurian romances. Eachtra an Mhadra Mhaoil, Eachtra Mhacaoimh-an-Iolair: The Story of the Crop-eared Dog, The Story of Eagle Boy, Irish Texts Society 10 (London, 1908). 
$1693 .{ }^{20}$ It contains three sections. The first contains the text of Séathrún Céitinn's Eochair Sgiath an Aifrinn (fols. 1-37), the second a translation of the Vita Christi into Irish by Tomás Gruama Ó Bruacháin (fols. 38-87), and the third, part of two poems on the residence built by Aodh Ó Conchubhair (d. 1309) at Cluain Fraoigh, county Roscommon.

\section{The edition and translation}

The text presented here is a diplomatic edition. No attempt has been made to arrive at a consistent spelling system. Historical texts traditionally favoured conservative spellings over contemporary spellings. Thus, the spelling system in any given text could exhibit in the main a conservative spelling system, but also an intrusive contemporary spelling system as a consequence of the scribe losing focus and allowing modernisms to slip into his text.

\section{Editorial policy}

Editorial intervention has been kept to a minimum. Expansion of scribal abbreviations has been indicated by the use of italicisation. The sineadh fada has not been supplied editorially to indicate vocalic length, except in the translation.

Ó Luinín has used uppercase letters to indicate section and sub-section headings. Some section headings and particularly important points of reference within the text have been rubricated. He has been inconsistent in many instances in his capitalisation of the initial letters of personal and place names. In such cases, I have printed an upper case initial. In all other respects, his punctuation has been retained, even when he has capitalised an initial letter where a modern writer would no longer do so. Modern word division has been imposed. Square brackets have been used, albeit sparingly, to indicate that something has been supplied by the editor. Angle brackets have been used to contain comments on the physical condition of the manuscript such as the occurrence of erasures. Three dots within angle brackets indicate that text has been lost through erasure, fragmentation or is so unclear as to be completely illegible.

A translation has been provided. As far as possible, it adheres to the layout of the Irish text which has been reproduced as it appears in the manuscript. A contextual commentary follows the text and translation.

\section{Some conclusions}

Circumstantial evidence suggests that Conchabhar Ó Luinín, a member of one of Ulster's most important scholarly families, wrote the present text at some time during the period 1650-1700, possibly in modern day county Cavan. It appears that he penned another of his manuscripts for one Ó Gabhann. The reference to members of the Uí Ghabhann family, the only non-Uí Raghallaigh people from

\footnotetext{
${ }^{20}$ Muintir Cionaith is anglicised as Muntir Kenny. It is located in the barony of Dromahair, county Leitrim. According to Hogan's Onomasticon Goedelicum, it encompasses the district between Lough Allen and the River Arigna.
} 
Bréifne to be mentioned in the text, might suggest an Ó Gabhann patron. There is, however, no firm evidence to support this suggestion. All that can be concluded with any certainty is that the present text was written in the second half of the seventeenth century or in the very early years of the eighteenth by Conchabhar Ó Luinín of Fermanagh. It emphasises the important role played by the Irish lords of south Ulster in the 1641 War.

\section{Acknowledgements}

I am grateful to the Library of the Royal Irish Academy in Dublin for granting me permission to publish Conchabhar Ó Luinín's Historical Tract from manuscript B i la (Catalogue Number 1078). I wish to express my gratitude to Dr. Uáitéar Mac Gearailt and Ms Sarah Wagstaffe for helping me to bring this article to publication. Dr Éamonn Ó Ciardha, Ulster University, kindly read an early draft of this article and provided me with suggestions for revisions and corrections.

\section{Diplomatic text}

6v: MÍLE SÉ CHÉUD DHÁ FHITHCHEAD AGUS

\section{BLIADHAIN AOÍS XP.}

an tan do tosuigheadh, 7 do dionignam $h$ le droing dúaislib $h$

Eírend an cogadh millteach mibheartach mallaithi ler chaill Goill agus

Gaoidhil Eireand a sé $\mathrm{n}$ Et a son $u s$ a rath, 7 a ratham $h \mathrm{n} u s$

Et a reim $h$ eas a fforba, a ffearuind $\mathrm{Et}$ a ffineoch $u s$ a m

bailte bunaidh a mbuair, 7 a mbó tháinte a nágh, 7 a nonóir,

7 a noireoch $u$ s et gurob an $n$ sa $\operatorname{cog} a d h \sin$ do thuit anuais-

le et an árdmhaithe Et ar ccriochnughadh an chogaidh a cciond

dhá bliadhan deúg do hiondarbadh gach air mhair da nuáislibh

don Sbáin $n$ et cco ccríochaibh imchíana oile. DO THAIRGFIN $N$

féin an cogadh sin do chur an neagar, 7 a nórdughadh muna beadh neach ag E-

íre nnachaibh atá a chlú no a caithréim, gidheadh do dheána

nóta Et coimhne air an mhéid dáruibh, 7 do mhad $h$ muib $h$

oirrdeirce ro tugad $h$ an $n$ ma gheibim a bfios go hiomlán

Ó THÚS $\mathrm{T}^{21} \mathrm{ugu}^{d}$ tosach dá ttug $a d h$ do mhadhmuibh, 7 dáruibh san

Midhe.

\section{// An dara bliadhain}

Maid $m$ Baile Shoilíain tugad $h$ ar Saxannachuibh le PILIP M $A$ C $\mathrm{AODH}_{\mathrm{A}}$ UÍ RAGHALL $A I G H, 7$ la feruib $h$ Breifne an ced bliadhain don 20 $\operatorname{cog} a d h$.

\footnotetext{
${ }^{21}$ This letter is more similar to a $d$ than a $t$. Note, however, that $t u$ - in ro tugadh in the line above is similarly written.
} 
Briseadh Thulaigh Áluin $n$ air Eireannachuibh [an] bhliadhain ché d ${ }_{\mathrm{a}}$ na

$<$ text erased $>$ air eir[eannachaib] $<$ text erased $>$

$<$ line erased $>$

7r: < ..> darbh alias mulach masden air Eírennachuibh

$<\ldots>$ gnach air Eírennachuibh

$<\ldots>$ go moirde lbha air Eíreannachuibh

$<\ldots>$ [Ti]ghe Molinn air Eirennachuibh

[Bri]seadh Chlún na nGall air Eirennachuibh

Briseadh Pháirce in Bloinnsi air Shaxannachuibh

Maid $m, 7$ ár Atha Clíath air Eírennachuibh

Ár Locha Garmann air Eírennachuibh

Briseadh Locha Garmann uáir eile air Eirennachuibh

MÁDHMA ET TRODA CHUIGIDH MUMHAN SUNDA.

Briseadh ag Mainistir Fhérmuigh air Shaxanachuibh.

Briseadh Lios Cearbhuill air Eireannachuibh.

Briseadh 7 retha Bhaile an Aírd ar Eíreannachuibh.

Briseadh dhroichid Thighe Mo Luige air Eireannachuibh.

Toghuil Chaisil Mumhon le Barún Innsi í Chuinn, 7 lé

Saxannachuibh anar marbhadh Sagairt agus Braithre

maille re hiomad oile déirendachuibh

$<$ text erased $>$ Saxannachuibh ag Clúin Meala

$<$ text erased $>$ Chnuic na nDos air chaindealuibh Eireand 7 Alban

[Iom ?] airc Alasdron $n$ mac Colla Chiotaig mhic

[Domh]nuill aonbhéol fer nEireand, 7 Alban an úair sin do

$<$ text erased $>$ gach. 7 ler thuit iomad do Ghallaibh

$---<$ entire line erased $>$

[MÁDHMA ET TRODA CHUIGIDH] CONNOCHT [SUNDA]

7v: Maid $m$ Sléibhe n Tuirc [?] air Eíreannachuibh

Briseadh ag Ros Comáin air Eíre[nnachuibh]

Briseadh ag Ros Camáin air Saxan[naibh]

Briseadh na Croisi riabhaigh air Saxannachuibh le Máolm[orrdha]

Briseadh Sligidh air Eíreannachaibh anar marbhadh áirdeaspocc

agus móran oile do mhathuibh Connocht

Briseadh laim re Gaillimh air Saxanachuibh * brian ua

Briseadh Mhoighe Fionncha air Eírennachuibh

Briseadh Shleibhe Roisil air Eirennea[c]huibh.

MADMA TRODA, ET AÍR CUIGEADH ULADH andso

Maid $m$ Bhun Doroige air Ghalluibh, Alasdrond mac Colla

Chiotaigh dob fhearr lam[h] and sin.

* Wr. in different hand. 
Maid $m$ Lios na cCearbhach air Eireannachuib $h$

Maid $m$ Ghlinne Cuind air Eirennachuibh Alasdron $n$ mac

Colla Chiotaigh do bfhearr lám[h] and sin.

Ár ad $h$ bhal mhór a cCeinél Fhairtigh air fhEruib $h$ air m $h$ náib $h$ et air leanbuib $h$ Eíren $n$.

Ár an $n$ ar marbhadh a roibh dfhearuibh do m $h$ náibh [et lean] bhuibh a nOilén Mheg Gáoth.

Ár ag Iúbhir Chionntrágha air Eiren $n$

achuibh et an $n$ ar báithead $h$ morán [?] dho [fhear?]

-uibh do mhnáib $h, 7$ do $1[$ eanbhuibh] <text erased $>$

$<$ text erased $>$ orduigh ris $\sin$ do $<$ text erased $>$

$<$ text erased $>$ abhadh do bhí s $<$ text erased $>$

9(8)r: doirbhir a ngeall air chomhthuibh bréige an baile ní fríth fios oidhe aríamh.

Ár ar Slíab $h$ cCuilin $n$ air fhearuibh air m $h$ náib $h, 7$ air leanb= uibh Eírennachuibh. Maid $m$ Clú $_{i}$ Éis $_{i}$ air Eogon Ua Néill, 7 air Mait $h$ ib $h$ chúigead $h$ Uladh.

MAIDHM NA BINNE BOIRBE alias Droma flithe air Ghalluibh, 7 Eogan Ó Néill agus uáisle Uladh ro chuir an maid $m$ sin an treas ár is mó tugadh air an ccogad $h \sin$ an Eírin $n$.

Maid $m$ Inis Scceillein $n$ air Eirennach $u i b h$.

Maid $m$ Lios na Srían air Eirennachuibh, 7 ar Albanachuibh.

Briseadh Dhroma Lighean air Saxanachuibh

MAID $H$ M NA SÚILIGHE ALIAS LEITIR

cceanu $_{\mathrm{i}}$ nd air eiren $n$ achuib $h$, áit sin in $a r$ cuirEd $h$ uáis-

le Uladh cco dit $h$ fine, 7 do rad Seilb Eíreand gan

imreasuin dfearuib $h$ Saxan $n$.

IS olc liom gan fhios agu $m$ ca líon do thuit dEíre $\mathrm{n} n$ achuibh dAlbanachuibh Et do Saxanachuibh an $n$ gach maid $m$ an $n$ gach briseadh, 7 an gach iomairce da ttugadh [and?] sin. Et mEsuim gur biot $h$ mhairg don muidhm

$<$ erasure $>$ sin Et ro thosuigheadh ar tús é do réir mur

$<$ erasure $>$ Inis Ceileann ar Aodh

$<$ erasure $>$ na air Feilim $<$ erasure $>$ rúag $h$.

$<$ final line completely erased $>$

9(8)v: ACC SO NA DAOÍNE UÁISLE

is oirdirce do thuit san $\operatorname{cog} a d h \sin$ on cuigead $h$ Uladh.

Sir Feidlim ruág $h$ ua Neill, do cu,readh cum báis an Áth Clíath. 
Concabhar Mhág Uidhir Tigearna Inis Ceilean $n$ do cuireadh chum báis a Lunnduin.

EASBOG Clochair do cu readh chonn [sic] báis an Innis Ceileann.

AODH Mac Mathghamna do cu readh com baís a Londoin $n$. mac Briain mic Aod $h$ [sic] Oíg, etc.

CONN mac Coin $n$ mic Neill mhic Briain Fhagartaigh

FEIDHLIM mac Tuathail mhic Neill $\mathrm{m}^{\text {ic }}$ Briain Fhagartaigh

$A R T$ mac Coinn mhic Seaain an Díomuis

Art Óg O Neill mac Toirrdhealbhaigh mhic Énrí mhic Feidlime. r[idire?]

TOIRRDHEALBHACH mac Briain Mhic Enrí oig Ui Neill

Magnus mac Neill Ghairb $h$ Í Dhom $h$ nuill

Aod $h$ buidhe mac Toirrdhealbhuigh mhic Cabhair Í Dhom $h$ nuill

AN DÁ Ó CHATHAN.

SÉMUS mac Goffraid $h$ Í Chathan fear lán diocht, dféile, 7 deine $\mathrm{ch}$

MAC SÉMUIS m $h$ ic Goffraigh .

MAGNUS RUAGH Ó Cathán

RUGRAIDH Mhág Uidhir

AODH MHÁG [Uidhir ?] mhic Briain

AODH Mh $<\ldots>$

$<$ rest of folio illegible $>$

10(9)r: AODH Mag Mathghamna mac Airt Oíg

ART mac Rúgraid $h$ m $h$ ic Giolla Phadraig

PÁDRAICC mac Eógu ${ }_{i}$ mic Rúgraid $h$

AODH ÓG mac Colla mic Eímhir mhic Briáin

PADR $U_{\mathrm{I}} \mathrm{CC}$ mac // Briáin m $h$ ic // Éim $h$ ir

ACC SO NA DAOÍNE IS OIRRDEARCA DO THUIT O BHREIF

NE Í RAGALLAIGH.

EOGHAN MAC SEÁAIN M ${ }^{\text {IC }}$ PHILIP

AODH RUAG $H$ MAC PILIP MIC AÓDHA

Maolmorrdha mac Pilib mhic Maolmorrdha

Maolmorrdha mac Cathaoír mic Seaain.

Maol Morrdha mac Seaain "Séadhach „na <erasure>

Toirrdhealbhach mac Catháoir mhic Eoghuin

Sémus mac Tomáis mic Semhuis Bhuidhe

Séan Óg O Raghallaigh. Semus mac Conchabhuir

$<\ldots>$ mac Séa ain mhic Aódha. Toirrdhealbhach mhac Cathail

mhic Aodha. Pilip Ó Gabann. Eogan Ó Gabhann.

Toirdhealbhach Óg O Boíghil mac Toirrdhealbhaigh.

$<\ldots>$ gh. LEU. COL. Do marbhadh a mbriseadh glean $n$ sulaigh $<\ldots>$ 


\section{Translation}

6v: THE YEAR OF OUR LORD ONE THOUSAND, SIX HUNDRED AND FORTY-ONE.

[That was] the occasion when there was begun and prosecuted by a group of the nobles

of Ireland the destructive, pernicious and accursed war as a result of which the foreigners and

the Gaeil of Ireland lost their prosperity and their happiness, their bounty and their abundance;

and their sway over their ancestral land, their estates and their patrimonies, their homesteads, their kine, and their cattle, their cows, and their honour, and their status[.] And it is in that war that there fell their nobility and their principal chiefs[.] And at the end of the war in twelve years time all that was left of their nobles had been banished to Spain and to other distant lands. I MYSELF WOULD PROPOSE to depict that war if it were not for the fact that there existed one among the Irish which is [already] famous or celebrated[.] Nevertheless, I will make a note and record of all of the slaughters and of the famous battles that were fought therein if I can ascertain full knowledge of them. At the start it was in Meath that the battles and massacres commenced.

\section{//The Second Year}

The battle of Julianstown was won by Philip son of Aodh Ó Raghallaigh and by the men of Bréifne over the English in the first year of the war.

The defeat of the Irish at Tullyallen [in the] same year.

$<$ text missing $>$

7r: The defeat of the Irish at the battle of $<$ text erased $>$ otherwise called Mullach Mast.

The defeat of the Irish at $<$ text erased $>$.

[a victory] was won against the Irish using great guile.

The defeat of the Irish at Timoline.

The defeat of the Irish at Clonegal.

The defeat of the English at Blanchville Park.

The defeat and slaughter of the Irish at Dublin.

The slaughter of the Irish at Wexford.

The defeat of the Irish again at Wexford.

HERE ARE THE MUNSTER BATTLES AND ENGAGEMENTS.

The defeat of the English at Fermoy.

The defeat of the Irish at Liscaroll.

The defeat and rout of the Irish at Ballinard.

The defeat of the Irish at the Bridge of Timoleague. 
The siege of Cashel by the Baron of Inchiquin, and by the English in which were killed Priests and Friars together with many others of the Irish [.] $<$ text erased $>$ of the English at Clonmel.

[The defeat] of the comely and shapely ones of Ireland and Scotland at Knochnanuss.

[The overwhelming of] Alasdar son of Coll Ciotach son of

Domhnall, united voice of the men of Ireland and of Scotland at that time

$<$ text erased $>$ and by whose hand many of the Foreigners had fallen.

$---<$ entire line erased $>$

HERE ARE THE CONNACHT BATTLES AND ENGAGEMENTS

$7 \mathrm{v}$ : The rout of the Irish at Slievetuirk [?].

The defeat of the Irish at Roscommon.

The defeat of the English at Roscommon.

The defeat of the English at Crosreavey by Maol Mórdha.

The defeat of the Irish at Sligo in which were killed the archbishop and many others of the gentry of Connacht.

The defeat of the English near Galway.

The defeat of the Irish at the Plain of Finnea.

The defeat of the Irish at Slieve Russell.

HERE ARE THE ROUTS, COMBATS, AND MASSACRES [WHICH

OCCURRED] IN THE PROVINCE OF ULSTER.

The rout of the foreigners at Bun Daroige, Alasdar son of Coll

Ciotach was the most effective there.

The rout of the Irish at Lisnagarvey.

The rout of the Irish at Glenmaquin. Alasdar son of Coll Ciotach was the most effective there.

A terrible massacre in Cineál Fhartaigh of the men and women and children of Ireland.

A massacre there in which were killed all the men and women and children in Island Magee.

A massacre of the Irish at Newry in which were drowned many of the men / and of the women and of the children.

$<$ two lines of text erased or badly damaged $>$

9(8)r: [There was a lot] of grief on account of the deceitful fellows of the town. Knowledge of the slaying was never discovered.

Massacre on Slieve Gullion of the Irish men, women and children. The rout of Clones was suffered by Eoghan Ua

(O) Néill and the gentry of the province of Ulster.

The rout of the foreigners at Benburb alias of Droim 
Fliuch, and Eoghan Ó Néill and the nobility of Ulster effected that rout, the third biggest slaughter that happened during that war in Ireland.

The rout of the Irish at Enniskillen.

The rout of the Irish and of the Scots at Lisnastrain.

The rout of the English at Drumleen.

THE ROUT OF THE SWILLY ALIAS LETTERKENNY

was suffered by the Irish. That was the place in which the nobility

of Ulster were brought to the point of being exterminated as a kin-group, and the possession of Ireland was given without a fight to the men of England.

Alas, I know not how many of the Irishmen and

Scotsmen and Englishmen fell in every battle and in every encounter that

occurred then. And I think that that cataclysm is a source of eternal regret.

And it was started first as $<$ erasure $>$

$<$ erasure $>$ Enniskillen on Aodh

$<$ erasure $>$ nor on Feidhlim Ruadh

$<$ final line completely erased $>$

9(8)v: HEREWITH ARE THE MOST ILLUSTRIOUS NOBLEMEN

who fell in that battle from the province of Ulster.

Sir Feidhlim Ruadh Ua Néill, who was put to death

in Dublin.

Conchabhar Mág Uidhir, the Lord of Enniskillen, who

was put to death in London.

The Bishop of Clogher, who was put to death in Enniskillen.

Aodh Mac Mathghamhna, i.e. the son of Brian son of Aodh Óg etc., who was put to death in London.

Conn son of Conn son of Niall son of Brian Fogartach.

Feidhlim son of Tuathal son of Niall son of Brian Fogartach.

Art son of Conn son of Seaán an Díomais [Shane the Proud].

Art Óg Ó Néill son of Toirrdhealbhach son of Énrí son of Feidhlim [knight].

Toirrdhealbach son of Brian son of Énrí Óg Ó Néill.

Maghnus son of Niall Garbh Ó Domhnaill.

Aodh Buidhe son of Toirrdhealbhach son of Cathbharr Ó Domhnaill.

The Two Cathánaigh.

Séamus son of Gofraidh Ó Catháin, a man full of mercy, of generosity and of honour.

Maghnus Ruadh Ó Catháin.

Rughraidh Mág Uidhir.

Aodh Mág [Mág Uidhir (?)] son of Brian.

Aodh $<$ text erased $>$

$<$ rest of page illegible $>$

10(9)r: Aodh Mac Mathghamhna son of Art Óg.

Art mac Rughraidh son of Giolla Pádraig. 
Pádraig son of Eoghan son of Rughraidh.

Aodh Óg son of Coll son of Éibhear son of Brian.

Pádraig son of // Brian son of // Éibhear.

HEREWITH ARE THE MOST ILLUSTRIOUS PEOPLE FROM O'REILLY'S

BRÉIFNE WHO FELL.

Eoghan son of Seán son of Philip.

Aodh Ruadh son of Philip son of Aodh.

Maol Mórdha son of Philip son of Maol Mórdha.

Maol Mórdha son of Cathaoir son of Seaán.

Maol Mórdha son of Seaán Séadach of the <erasure $>$

Toirrdhealbhach son of Cathaoir son of Eoghan.

Séamus son of Thomas son of Séamus Buidhe.

Seán Óg Ó Raghallaigh. Séamus son of Conchubhar.

? son of Seaán son of Aodh.

Toirrdhealbhach son of Cathán

son of Aodh. Philip Ó Gabhann. Eoghan Ó Gabhann.

Toirrdhealbhach Óg Ó Baoighill, the son of Toirrdhealbhach.

$<\ldots$.. . LEU. COL. <illegible $>$ He was killed at the battle of Glenswilly.

\section{Commentary}

6v11-12. DO THAIRGFINN // féin an cogadh sin do chur an neagair is a nordughadh muna beadh neach ag Eíre ${ }_{\mathrm{a}}$ nachaibh atá a chlú no a caithréim] We could read DO THAIRGFINN // féin an cogadh sin do chur an neagair is a nordughadh muna beadh neach ag Eire nnachaibh atá a cclú no a ccaithréim and translate 'I myself would propose to depict that war if it were not for the fact that there existed one among the Irish which is [already] famous [ $i$ cclu' 'in fame'] or celebrated [i ccaithréim 'in triumph'].' Is this perhaps a reference to the existence of the Cín Lae Ui Mhealláin? For the text of the latter see Tadhg Ó Donnchadha (ed.), 'Cín lae Ó Mealláin', Analecta Hibernica 3 (1931), 1-61. See now, M. Nic Cathmhaoil, The seventeenth century text 'Cín lae Ui Mhealláin' with introduction, translation and notes (Coleraine, unpublished $\mathrm{PhD}$ Thesis, Ulster University, 2006). The text is in Cork, UCC, Murphy Collection, MS 3; digital images of the manuscript can be seen at: https://www.isos.dias.ie/irish/index.html (accessed 24 August 2017). See also B. Ó Conchúir, Clár Lámhscríbhinní Gaeilge Choláiste Ollscoile Chorcai: Cnuasach Ui Mhurchú (Dublin, 1991) 8-9. References here are to the manuscript pages as given in Ó Donnchadh's edition.

6v19. Maidm Baile Shoilían] The battle of Julianstown, Co. Meath occurred on 29 November 1641 when an English army on its way to restore order in Ulster was defeated by the Irish under Ruaidhrí Ó Mórdha (Rory O’Moore). This placename is 
written as 'Baile Giollan' in Ó Donnchadha, 'Cín lae', 31. Lenihan noted that most of the 'local Catholic nobility and most of the gentry still backed the government' until this incident: see Lenihan, Confederate Catholics at War, 34.

6v19-20. Pilib [mac Aodha mic Sheáin mic Aodha Conallaigh] Ó Raghallaigh] Hunter states as follows: 'The two principal O'Reilly grantees were Mulmory oge [Maol Mórrdha Óg] and Mulmory McHugh Connelagh [Maol Mórrdha mac Aodha Conallaigh]. As to Mulmory oge, we have already seen that substantial portions of his estate were dispersed. He died without heir in 1617, the remaining lands descending to his uncle Capt. Hugh, whose son, Philip McHugh O'Reilly, owned much of them in 1641.' Cf. R. J. Hunter, The Ulster plantation in the counties of Armagh and Cavan, 1608-41 (Belfast, 2012), 216.

Pilib son of Aodh son of Seán son of Aodh Conallach Ó Raghallaigh, leader of the Irish army in county Cavan, lived at Béal Átha na Carraige Castle in the parish of Drung, barony of Tullygarvey. He was elected to the Irish Parliament in 1639. He captured Belturbet in 1641, but was unsuccessful in capturing Drogheda in 1642. As one of the colonels of Eoghan Ruadh, he fought at the battle of Benburb. After the final defeat of the Irish in 1653, he went into exile in Spain. He left Spain for the Lowlands in 1654 and died in 1655. He is buried in the Priory of St Dominic in Louvain. His exile is lamented in the poem entitled Tuireamh Philip meic Aodha Uí Raghallaigh, which begins Mo chreach is mo léun thú, [a] Bhēul Atha na Cairrge: see J. Carney, Poems on the O'Reillys, 139-46. His genealogy is given in J. Carney, A genealogical history of the O'Reillys (Cavan, 1959), 27, § 3. See also Ó Donnchadha, 'Cín lae', 31, sub 1641 Nov. 29. See also, B. Mc Grath, 'A biographical dictionary of the Irish House of Commons, 1640-1641' (unpublished Trinity College $\mathrm{PhD}$ thesis, 1998).

Gilbert listed the companies of Colonel Pilib mac Aodha Uí Raghallaigh's regiment at Clonmel in January 1649-50. They included those commanded by the following Uí Raghallaigh: (3) Brian; (4) Seán; (6) Maol Mórrdha; (7) Seán Óg; (8) Maol Mórrdha son of Éamonn; (9) Maol Mórrdha son of Aodh and (11) Pilib Ó Gabhann: see Gilbert, A contemporary history of affairs in Ireland from 1641-1652, 3 vols.; two parts in each (Dublin, 1878-1880), ii, 503-04.

6v22. Briseadh Thulaigh Áluinn] The battle of Tullyallen (53 44 N; 624 W), Co. Louth occurred around the time of the First Siege of Drogheda. I draw on Donald Schlegel's account of the siege in 'A Clogher Chronology 1641-2', Clogher Record 16.1 (1997), 79-94, at 89-91. The Irish attempted to take Drogheda on 20 December 1641, but were repelled by its English defenders. A siege ensued during which the Irish again unsuccessfully assailed the walls on 20 February 1642 . Failure by the Irish to cut off the town's maritime approaches meant that its defenders were able to bring in reinforcements and food. The garrison commander led a successful foray against the O'Reillys to the south and followed this with another foray to the north about a week later. Schlegel (p. 90) writes: 'On Saturday, March 5, the governor of the town led a force against the O'Neills' camp at Bewley and burned Newton. 
At the same time Lord Moore led 400 foot and 80 horse toward the McMahon and McKenna camp at Tullyallen. Many of the Monaghan men had entrenched themselves in the centre of the town, but they had little powder for their muskets. After exchanging three or four volleys they had to give way. Elsewhere on the field the Irish discerned Lord Moore and a large body of them attacked and wounded him, but were scattered by some of his horse. Some four hundred of the Irish were killed, including seven of their captains.'

7r1. Mulach Masden] The Irish army under the command of Viscount Mountgarret was defeated at the Battle of Mullaghmast near Kilrush, Athy, Co. Kildare by the Marquis of Ormond on 15 April 1642. The form 'Mullach Maistean' is found in the poem An Síogaí Rómhánach: see C. O’Rahilly (ed.), Five seventeenth-century political poems (Dublin, 1977), 12-32, at 31.

7r3. <...> go moirde lbha air Eíreannachuibh] There appears to have been an attempt to erase the letter -e- in dealbha which would give dalbh, genitive dailbhe. Dinneen defined this word as 'a lie, fiction, guile'; I suggest that this fragmentary line means something like: '[a victory] was won against the Irish using great guile'.

7r4. Briseadh Mo Linn] The Marquis of Ormond left Dublin on 2 March 1643 with the intention of taking the port town of New Ross, Co. Wexford so that the channels of communication between Kilkenny on the one hand and Waterford and Wexford on the other could be broken. On his way to New Ross via Timolin, Ormond eventually overcame stout resistance at Timolin Castle in south Kildare. The castle had been secured early in the war by Mac Thomáis and Gerald FitzGerald: see Ó Donnchadha, 'Cín lae', 34.

7r5. Briseadh Clu[a]in na nGall] Battle of Clonegal, south-east Carlow. I have been unable to identify the details of this encounter.

7r6. Pháirce in Bloinnsi] The location is Páirc in Bhlóinsínigh (Blanchvillespark), parish of Gowran, barony of Gowran, Co. Kilkenny. I have been unable to identify the details of this encounter.

7r7. Átha Cliath] This may be a reference to the defeat of the Irish under Ormond at the battle of Rathmines in October 1649: see D. Edwards, The Ormond lordship in county Kilkenny, 1515-1642: the rise and fall of Butler feudal power (Dublin, 2003).

7r8. Ár Locha Garmann air Eírennachuibh] On 2 October 1649 Cromwell arrived to besiege the town of Wexford with a force of 6,000 men. The town was successfully stormed by the Parliamentarians on 11 October 1649. The 'Aphorismical discovery of treasonable faction' in Gilbert, Contemporary history, ii, Part 1 (Dublin, 1880), 54 tells us, 'Marchinge on, noe opposition was giuen, slaughteringe all that came in his [Cromwell's] way, without exception of sex or person, age or condition, onely such as were of the conspiracie; many of the soldiers for the most part Vlstermen, My Lord of Iveaghs regiment) saved themselves by boats and swiminge, but great 
mortalitie did accompanie that furie of both souldier and native, all sex and age indifferently there perished ...'

7r11. Briseadh ag Mainistir Fhérmuigh] The Confederate Catholics under James Tuchet, the Earl of Castlehaven, defeated a Munster Protestant Royalist army under the command of Sir Charles Vavasour on 4 June 1643 on a site that is located between the river Funcheon and the river Blackwater to the north of the town of Fermoy. The engagement is known by various names: the battle of Cloghleagh/ Funcheon Ford/Manning Water.

7r12. Briseadh Lios Cearbhuill] In July 1642 Murrough O'Brien, Lord Inchiquin, was victorious over a 6,000-strong Irish army led by Garrett Barry at Liscarroll, Co. Cork. As a consequence of this battle, Munster was secured for the king. The 'Aphorismical discovery of treasonable faction' in Gilbert's Contemporary history, i, Part 1 (Dublin, 1878), 38 states: 'Monster was in a brave posture at this time, the enemie was there stickinge to one moytie of the countie of Corke, and if not for the Baron of Insichuyne, an Irishman of the Brians, the enemie likly would have never a foote there.' See Patrick Little, 'O'Brien, Murrough, first earl of Inchiquin (c. 1614-74)', Oxford Dictionary of National Biography, Oxford University Press, 2004, http://www.oxforddnb.com/view/article/20463 (accessed 15 February 2016).

7r13. Briseadh 7 retha Bhaile an Aírd] The details of this encounter which happened at Baile an Aird, possibly Ballinard Castle, near Fethard in south Tipperary are obscure.

7r14. Briseadh dhroichid Thighe Mo Luige] The encounter at Timoleague Bridge may have coincided with the destruction of Timoleague Friary in 1642.

7r15. Toghuil Chaisil Mumhon] Cashel was sacked by Lord Inchiquin on 15 September 1647.

7r18. Clúin Meala] The siege of Clonmel occurred between April and May 1650. The Irish were led by Aodh Dubh Ó Néill who commanded an army of 2,000 against a besieging army of 8,000 Parliamentarians. For an account of the siege, see 'Aphorismical discovery of treasonable faction' in Gilbert, Contemporary history, ii, Part 1, 75-80, at 79; see also J. T. Gilbert, 'O'Neill, Hugh, styled sixth earl of Tyrone (d. 1660/61)', Rev. P. Lenihan, Oxford Dictionary of National Biography, http://www.oxforddnb.com/view/article/20776 (accessed 15 February 2016).

7r19. Chnuic na nDos] Alasdar mac Colla Ciotaigh Mhic Domhnaill (Sir Alasdar Macdonald) was tánaiste (heir-apparent to the leadership) of the Clann Iain Mhóir branch of the Clann Domhnaill of the Isles. This son of Coll Ciotach son of Giolla Easpaig and Màiri the daughter of Raghnall Mac Domhnaill of Benbecula was born in Colonsy. While his Christian name appears in our text as Alasdron, variants in Alasdrom and Alasdar are also common.

With the commencement of the war in 1641, Alasdar found himself in a Scottish regiment in Coleraine that had been ordered to suppress his Irish kinsmen. Together 
with a group of fellow highlanders, he detached himself from his regiment and rallied to the Irish cause, fighting at Sir Feidhlim Ó Néill's side at the battle of Glenmaquin in county Donegal on 16 June 1642. Among the injured was Alasdar, who returned to Scotland in July 1644 to fight successfully alongside the Earl of Montrose. Their combined Gaelic-Royalist army won several great victories. Alasdar's decision to leave the side of Montrose to return to the Highlands to give the coup de grâce to the Campbells had serious consequences for Montrose. The latter suffered a serious defeat at Philiphaugh in September 1645. King Charles subsequently ordered the royalist armies to stand down in mid-1646. Montrose did so and went into exile; Alasdar did not.

Mac Domhnaill was driven off the Scottish mainland and onto Islay, but quickly abandoned it for Ireland and took with him the remnants of his army. He saw action as a senior commander with Lord Taaffe's Munster Irish army at Clonmel. The Irish were subsequently defeated by Lord Inchiquin's Munster Protestant army at Cnoc na nDos (Knocknanuss) on 13 November 1647. Alasdar was captured after the battle and shot.

For Alasdar's biography, see David Stevenson, Alasdair mac Colla and the Highland problem in the seventeenth century (Edinburgh, 1980). See also Lenihan, Confederate Catholics at war, 106 on Knocknanuss and 193-97 on Alasdar mac Colla's battle tactics.

The poem entitled Aiste Dháibhí Cúndún, beginning Is buartha an cás so 'dtárlaig Eire ('Sorrowful the situation in which Ireland has found itself'), was dated by O'Rahilly (Five seventeenth-century political poems, 46) to between 1654 and 1657. It contains the following lines:

is ó lá Chnuic na nDos ba dhéarach ionar fealladh ar Alasdram éachtach. 'and from the day of [the battle of] Kocknanuss, which was tearful, during which was treacherously slain Alasdar of the many feats of battle.'

7v1. Maidm Sléibhe $\mathbf{n}$ Tuirc] I have not been able to identify this encounter.

7v2. Briseadh ag Ros Comáin] On 10 July 1646 General Preston captured Roscommon Castle for the Irish Confederacy, an achievement which Lenihan has regarded as a 'relatively insignificant one'. See Lenihan, Confederate Catholics at war, 189.

7v4. Briseadh na Croisi Riabhaigh] An unidentified encounter in Crossreagh townland in county Cavan. For Maol Mórdha Ó Raghallaigh's background, see Eoghan Moore, “"Mulmorie Oge O’Reylie, gent." alias Maol Mórdha Óg Uí Raighaillaigh of Bellanacargy', Breifne 50 (2015), 572-79.

7v5. Briseadh Sligidh] Charles Coote captured Sligo for the Parliamentarians on 7 July 1645. P. J. Corish noted that the Archbishop of Tuam, Maolseachlain Ó Caollaidhe (1586-1645; Malachy Queally), lost his life under disputed circumstances at Ballisadare, Co. Sligo on 25 October 1645. See 'Queally, Malachy 
(1586-1645)', Oxford Dictionary of National Biography, http://www.oxforddnb. com/view/article/22937 (accessed 15 February 2016).

7v7. Briseadh laim re Gaillimh] Possibly, Seán a Búrca's capture of Galway in 1643.

7v8. Briseadh Mhoighe Fionncha] The Irish repelled the Scots at the bridge of Finnea $(5346 \mathrm{~N}, 723 \mathrm{~W})$ in county Westmeath on 5 August 1646. One of the English spellings given in the index to Gilbert, Contemporary history (iii, Part 2, Index, p. 418) is Finnawe. This form comes from Fionncha an Mhaighe whereby the order of the elements of this toponym have been rearranged. On 'Myles the Slasher' of popular tradition, see also J. J. O'Reilly, The history of Breifne O'Reilly (New York, 1976); reference here is to the Long Riders' Guild Press reprint (no place; no date), 111-12. See P. Walsh, 'Colonel Myles O'Reilly', in Irish chiefs and leaders (Dublin, 1960), 175-79.

7v9. Briseadh Shleibhe Roisil] In his discusion of Colonel Maol Mórdha $O$ Raghallaigh, Walsh noted a reference to the encounter at Slieve Russell that has survived in a genealogical tract in the hand of Tadhg Ó Neachtain in Dublin, Trinity College, MS H 115 (No. 1289); see Walsh, Irish chiefs and leaders, 171-72. Combat involved Captain Galbraith and twelve other officers. Such was Maol Mórdha's skill in battle that no member of his troop was injured other than himself; indeed, his own wounds were said to have been superficial.

7v11. Maidm Bhun Doroige] This encounter occurred in Co. Antrim in 1642: 'The next meeting of the British and Irish was at Bunderaga near the Crosses in the Route. The British of Coleraine marched out under the command of Archibald Stewart of Ballintoy, and other Officers, to the number of 600 Men and a Troop of Horse to get a prey. On which the Alarm was up, and the Irish under the Command of Alexander MacColla MacDonald, to the number of six or seven hundred Men, charged them in Boggie Ground, and beat their horse in amongst their Foot, and followed them in their Rear, and without any great Opposition took the Rout, which was the ruin of the most of them, leaving their colours with the Enemy. This was a fatal Break to the British in these Parts ...': see E. Hogan (ed), The history of the warr of Ireland from 1641 to 1653 by a British officer of the regiment of Sir John Clottworthy (Dublin, 1873), 22. The location is where the Claughrey Water enters the Ballymoney river near the townland of Bendooragh in the parish of Upper Ballymoney: see 'Bun Dubhraighe' in P. Ó Riain, D. Ó Murchadha and K. Murray (eds), Historical dictionary of Gaelic placenames, Fascicle 2 (Names in B-), 222.

7v13. Maidm Lios na cCearbhach] On 6 December 1649 the Parliamentarians under General Charles Coote defeated a Royalist army led by Lord Clandeboye and Major General Munro near Lisburn.

7v14. Maidm Ghlinne Cuind] On 16 June 1642 the Lagan Army under Sir Robert Stewart and Sir William Stewart inflicted a heavy defeat on the Irish under Sir 
Feidhlim Ó Néill and Alasdar mac Colla Ciotaigh at Glenmaquin in Donegal. Alasdar was badly injured in that encounter. See K. McKenny, The Laggan army in Ireland, 1640-1685: the landed interests, political ideologies and military campaigns of north-west Ulster settlers (Dublin, 2005). Lenihan reckoned this battle to have been among the seven largest encounters of the period 1642-43: see Confederate Catholics at war, 69.

7v16. Ár adhbhal mhór a cCeinél Fhairtigh] This should be read as Ceinél Fhaghartaigh. That population group was located in the barony of Kinelarty, in south Down. Mac Artáin was the lord of the Ceinél Faghartaigh. The massacre has not been identified.

7v19. a nOilén Mheg Gáoth] Island Magee is a peninsula which is attached to the county Antrim mainland by a causeway. The Scottish army of east Ulster killed a number of the Irish residents of Island Magee on the night of 8 January 1642: see E. Darcy, A. Margey and E. Murphy, The 1641 depositions and the Irish Rebellion (Abingdon, 2016), 134-38; see also John Gibney, "What about Islandmagee?" Another version of the 1641 rebellion', History Ireland, 21:1 (January/February 2013), 22-25.

7v20. Ár ag Iúbhir Chionntrágha] Kenneth Nicholls remarks: 'On 15 July 1642 Monroe's forces slaughtered 40 men and over 500 women and children who were fleeing southwards with their cattle over the mountains between Newry and Dundalk: the Irish, who were out of gunpowder, were unable to make any effective resistance, although they did manage to kill a few irregulars attached to the army.' See 'The other massacre: English killings of Irish, 1641-2' in D. Edwards, P. Lenihan and C. Tait (eds), Age of atrocity: violence and political conflict in early modern Ireland (Dublin, 2007), 176-91, at 190; see also T. Fitzpatrick, The bloody bridge, and other papers relating to the insurrection of 1641 (Dublin, 1903), xiii (from TCD MS 840, f. 23).

9(8)r3. Ár ar Slíabh cCuilinn] Unidentified massacre at Slieve Gullion, Co. Armagh.

9(8)r4. Maidm Clúin Éisi] On the 13 June 1643 the Laggan army defeated the Irish under Eoghan Ruadh Ó Néill at Clones: see P. B. Ó Mórdha, 'The battle of Clones, 1643', Clogher Record 4:3 (1962), 148-54.

9(8)r6. Maidm na Binne Boirbe] On 5 June 1646 Robert Monro's army was defeated by Eoghan Ruadh Ó Néill's army at Benburb: see 'Benburb, 1646' in G. A. Hayes-McCoy, Irish battles (London, 1969) 174-99.

9(8)r10. Maidm Inis Scceilleinn] Enniskillen and Tully Castle did not fall to the Irish during the 1641 war. See W. Copeland Trimble, The history of Enniskillen with reference to some manors in Co. Fermanagh: and other local subjects (3 vols, Enniskillen, 1919-21). 
9(8)r11. Maidm Lios na Srían] Hogan (Onomasticon Goedelicum) lists this place name under the form Lios na Sraon. He noted that Ó Ragallaigh destroyed it and gives the reference ' $\mathrm{Hx}$ 853'. It is situated to the south-east of the town of Lisburn and appears in English as Lisnastrean. It is in the civil parish of Drumbeg, barony of Castlereagh Upper, county Down. Rev. George Hill, The Montgomery manuscripts (1603-1706) (Belfast, 1869), has the following note (191-92): 'Our third Viscount with his few loyal followers and adherents, and the Earle of Clanbrasil, with his men (all that were preaching proof); their Lordships kept their forces together, and being personally present (as they were afterwards with Ormond) and by their example encouraging their soldiers, were routed at Lisnestrain (as it was said by Sir George Munro's mismanagement near Lisnegarvey aforesaid) by Sir Charles Coote and a party of O. C. army; Clanbrasil shifting with some flying horse, and his castle of Killyleagh standing out, he resorted to Ormond.'

9(8)r12. Briseadh Dhroma Lighean] Drumleene is in the civil parish of Clonleigh and in the barony of Raphoe North. It is situated to the north-west of Lifford. The details of this encounter are unknown to me.

9(8)r13-14. Maidhm na Súilighe alias Leitir Cceanuind] The disastrous defeat of the Irish under the command of Bishop Éibhear Mac Mathghamhna occurred at Scariffhollis, two miles to the west of Letterkenny on 21 June 1650. This particular rout marked the end of the Irish army: see J. Silke, 'Scariffhollis 1650', Clogher Record 20:3 (2011), 491-99, at 499.

9(8)v3-4. Sir Feidlim ruágh Ua Neill] Sir Feidhlim (1603-53), son of Toirrdhealbhach son of Énrí Óg son of Énrí son of Seaán son of Conn son of Énrí son of Eoghan, was Coronel na Marcshluagh ('Colonel of the Horse Regiments') and President of the Province of Ulster: see Ó Donnchadha, 'Cín lae'; Jerrold I. Casway, 'O'Neill, Sir Phelim Roe (1603-1653)', Oxford DNB; online edn, http://www. oxforddnb.com/view/article/20784 (accessed 2 December 2015). See also, 'The Irish Revolt' in Ó Doibhlin, Domhnach Mór, 108-35.

9(8)v5. Concabhar Mhág Uidhir Tigearna Inis Ceileann] Conchabhar Mág Uidhir, the Second Baron of Enniskillen (c. 1612-45) and son of Róis Ní Néill and Brian Ruadh Mág Uidhir, encouraged Eoghan Ruadh Ó Néill to return to Ireland to lead the Rising. He also participated in the plan to capture Dublin Castle. The betrayal of the plot led to his arrest along with that of Aodh Mac Mathghamhna (Hugh McMahon). Confined to the Tower of London in June 1642, they were eventually transferred to Newgate Prison. On 18 August 1644, Mac Mathghamhna and Mág Uidhir escaped from Newgate. They were reapprehended on 18 September 1644. Mág Uidhir endured the rack and a particularly brutal execution on 20 February 1645. See Brian Mac Cuarta, 'Maguire, Connor, second baron of Enniskillen (c. 1612-1645)', Oxford DNB; online edn, http://www.oxforddnb.com/view/article/17790 (accessed 16 November 2015). For the Méig Uidhir participation in 1641, see Donald M. Schlegel 'An index to the insurgents of 1641 in the county Fermanagh depositions', Clogher Record 18:2 
(2004), 319-40. The poem, An Siogai Rómhánach describes Mág Uidhir as fuigheall na Féinne 'of the remnants of the Fianna'; see O'Rahilly, Five seventeenth-century political poems, 23, line 117.

9(8)v7. Easbog Clochair] Éibhear son of Maoleachlainn son of Art Mac Mathghamhna, a native of Kiltybegs, parish of Inishkeen, in the territory of Clancaroll, Farney, Co. Monaghan, studied at the Irish College of Douai and then the Irish Franciscan College at Louvain. He returned to Ireland in 1633, eventually becoming Vicar-General. Appointed Bishop of Down and Conor in February 1642 and subsequently transferred to Clogher, the bishop found himself at the heart of many of the important political events that happened in Ireland between 1641 and 1650. Having assumed the role of leader of the Ulster Irish after the death of Sir Feidhlim in late 1649, Mac Mathghamhna led the Irish to a disastrous defeat at the hands of Sir Charles Coote at the battle of Scariffhollis on 21 June 1650. Badly wounded, he escaped to Enniskillen where he was arrested, imprisoned and eventually hanged: see Silke, 'Scariffhollis 1650'; W. Kelly, 'Forlorn alliances, the Ulster army and the battle of Scarrifhollis' in L. Ronayne (ed), Scarrifhollis (Donegal, 2001), 27-40; P. B. Ó Mórdha, 'The MacMahons of Monaghan (1600-1640)', Clogher Record 2:2 (1958), 311-27; S. P. Ó Mórdha, 'Heber Mac Mahon, soldier-bishop of the confederation of Kilkenny', Clogher Record 3, Clogher Record album: a diocesan history (1975), 41-62.

9(8)v 8-9. Aodh mac Mathghamna mac Briain mic Aodh Ó́g] This is Aodh Óg, the son of the Lord of Dartrey, namely, Brian son of Aodha Óg son of Aodh son of Seaán Buidhe. His mother was Lady Máire Ní Néill, daughter of Aodh Mór. He was executed for treason at Tyburn in November 1644: see Ó Donnchadha, 'Cín lae', 1; see also P. Lenihan, 'Mac Mahon, Hugh Oge (1606/7-1644)', Oxford DNB, http:// www.oxforddnb.com/view/article/17686 (accessed 2 December 2015).

9(8)v10. Conn mac Coinn mic Neill mhic Briain Fhagartaigh] Colonel Conn Óg son of Conn son of Niall son of Briain Fogartach son of Niall Óg son of Niall Mór of Clann Aodha Buidhe/Clandeboy died at battle of Clones: Ó Donnchadha, 'Cín lae', 17; see also ibid., 9 .

9(8)v11. Feid $h$ lim mac Tuathail $m h$ ic Neill $\mathrm{m}^{\text {ic }}$ Briain Fhagartaigh] LieutenantColonel Feidhlim son of Tuathal son of Niall son of Brian Fogartach of the Clann Aodha Buidhe. He fought at the battle of Scarbh Sholuis: see Ó Donnchadha, 'Cín lae', 34, 44.

9(8)v12. ART mac Coinn mhic Seaain an Díomuis] Éamonn Ó Doibhlin depicts the genealogy of Art Óg mac Cuinn mhic Seaáin an Díomais in O'Neill's own country and its families (Donaghmore, 1998), 171. His sons were Aodh Dubh, Seán and Conn Ruadh.

9(8)v14. Art Óg O Neill mac Toirrdhealbhaigh mhic Énrí mhic Feidlime] Colonel Art Óg son of Toirrdhealbhach son of Énrí na nGarrthan son of Feidhlimidh 
Ruadh Ó Néill of Tullydonnel in the Fews, S. Armagh: see Ó Doibhlin, O'Neill's own country and its families, 177. He was captured in September 1644: Ó Donnchadha, 'Cín lae', 25; see also T. Ó Fiaich, 'The O'Neills of the Fews', Seanchas Ardmhacha 7:2 (1974), 263-315.

9(8)v14. Toirrdhealbhach mac Briain mhic Enrí oig Ui Neill] See Ó Donnchadha, 'Cín lae', 27. First cousin of Sir Feidhlim and nobleman of Muintir Birn and Tuath Threana (Touranny).

9(8)v15. Magnus mac Neill Ghairbh Í Dhomhnuill] Maghnus died at the battle of Benburb: see Ó Donnchadha, 'Cín lae', 38.

9(8)v16. Aodh Buidhe mac Toirrdhealbhuigh Mhic Cabhar Í Dhomhnuill] For this soldier's involvement as a leading officer see 'Colonel Henry O'Neill's relation of transactions of general Owen Neill and his party' in Gilbert, Contemporary history, iii, Part 2 (Dublin, 1880), 196-216, at 206.

\section{9(8)v18. Sémus mac Goffraidh Í Chathan] Unidentified}

9(8)v19. mac Sémuis mhic Goffraigh] Unidentified.

9(8)v21. Magnus Ruagh Ó Cathán] At least two, and possibly three, leading members of the Uí Chatháin bore the name Maghnus Ruadh in the first half of the seventeenth century. The first of those was Colonel Maghnus Ruadh son of Cumhaigh Ballach son of Risteard Ó Catháin, who was killed in July 1645: see 'Cín lae', 31. 'Collonel Manus Roe o Cahan' is referred to in Armagh Deposition 67 (Michael Harrison, Lisnagarvey, Co. Antrim, 11 February 1653; p. 106); see A. Clarke et al. (eds), 1641 Depositions (Dublin, 2014) i, $106=$ TCD MS 836, fol. $133 \mathrm{v}, 2420$; online at http://1641.tcd.ie/deposition.php?depID=836127r068. A second Maghnus Ruadh, the son of Séamus son of Gofraidh Ó Catháin, resided near Loughgall in north Armagh. This 'Manus Roe Ó Cane of the Parish of Armaghe' is mentioned in Armagh Deposition 46 (Vol. 1; Joan Constable, Drummad, 6 June 1643); see Clarke et al. (eds), 1641 Depositions (Dublin, 2014) i, $68=$ TCD MS 836, fol. 87r, 427); online at http://1641.tcd.ie/deposition.php?depID=836087r046. He may have been one and the same as the 'Colonell Manus roe O' Cahan' who lost his life at the defence of Tóchar, county Louth in 1651; see Gilbert, Contemporary history, ii, 137 = 'Aphorismical discovery of treasonable faction', Book 5, Chapter 1. Finally, An Act for the Settling of Ireland (August 1652) lists a 'Colonel Manus Roe O Cahan' among the Irish soldiers excepted 'from pardon for life and estate': see Gilbert, Contemporary history, iii, Part 2, 341-44 at 343.

9(8)v1. Rugraidh Mhág Uidhir] Possibly, Colonel Rughraidh Mág Uidhir of Maguire's Bridge, brother to Lord Maguire: see Cavan Deposition 160 (A. Clarke et al. (eds), 1641 Depositions, ii, 105-06 = TCD MS 832, fol. 165r; online at http://1641.tcd.ie/deposition.php?depID=832165v161; Francis Lovett, Clonen; n.d.); he was captured in September 1644: Ó Donnchadha, 'Cín lae', 25. 
10(9)r1. Aodh Mhag Mhathghamna mic Airt Oíg] Aodh son of Art Óg Mac Mathghamhna. Possibly one and the same as 'Hugh mc Art Roe mc Sir Patrick mc Art Moyle mcmaghan of Annaghae, Gent.', Schlegel's Index, 83b: see 'Hugh mc Art Roe mc Mahone gent,' in Monaghan Deposition 259 (A. Clarke et al. (eds), 1641 Depositions, i, $255=$ TCD MS 834, fol. 143v; online at http://1641.tcd.ie/deposition. php?depID=834143r118; Henry Steele, Clontibret, 10 January 1642).

10(9)r2. Art mac Rúgraidh mhic Giolla Phadraig] Art son of Rughraidh son of Giolla Pádraig Mac Mathghamhna was captured on 5 March 1642. His brother, Rughraidh, was killed: Ó Donnchadha, 'Cín lae', 4. Art mac Rughraidh appears as 'Art Roe mc Rory mcMahone genteleman' in Monaghan Deposition 259 (Clarke et al. (eds), 1641 Depositions, i, 255-56 = TCD MS 834, fol. 144v; online at http://1641.tcd.ie/deposition.php?depID=834143r118; Henry Steele, Clontibret, 10 January 1642 (p. 256)).

10(9)r3. Pádraicc mac Eóguin mic Rúgraidh] 'Patrick mc Owin mc Rory mcmaghan of Ballelisnesomane, Barony of Dartrey'; Schlegel's Index, 87. See also 'Patricke mcOwen mcRowry mcMahone of Ballelisnespinane' in Monaghan Deposition 227; Matthew Browne, Clones, 24 March 1642 (Clarke et al. (eds), 1641 Depositions, i, 221 = TCD MS 834, fol. 100r; online at http://1641.tcd.ie/deposition. php?depID=834100r085).

10(9)r4. Aodh Óg mac Colla mac Eímhir mhic Briáin] I have not as yet identified this person, but see below.

10(9)r5. Padruicc mac // Briáin mhic // Éimhir] This entry should perhaps be read as: Pádruicc mac Éimhir mhic Bhriain. He is probably one of the four brothers mentioned in the entry: 'Patrick mc Ever mcmaghan, and four brothers, near Castleblaney'; Schlegel's Index, 54.

10(9)r8. Eoghan mac Seáain $\mathbf{m}^{\text {ic }}$ Philip] For the genealogy of Clann tSeáin mhic Pilip Óig Uí Raghallaigh, see J. Carney, A genealogical history of the O'Reillys, $\S 27$ (pp. 51-52). He appears as 'Owen mc Shane mc Phillip Rellie' in Deposition 319 (Vol. 2; Francis Graham, Drumgoon, 2 November 1642). P. Walsh has: Eoghan $m$ Seáin $m$ Pilip do marbhadh 1649; see 'Notes on the O'Reilly Family' in C. O Lochlainn (ed.), Irish chiefs and leaders: studies by Paul Walsh (Dublin, 1960), 141-56, at 145, entry 32.

10(9)r9. Aodh Ruagh mac Pilip mic Aódha] He is referred to as 'Hugh Roe Ó Rely' of the parish of Kilwater [Cill Uachtair] in Cavan Deposition 61 (A. Clarke et al. (eds), 1641 Depositions, ii, 73 = TCD MS 832, fol. 80r; online at http://1641.tcd. ie/deposition.php?depID=832080r061; Marmaduke Bateman, Ballyhaise, 13 April 1643). Drawing on Dublin RIA MS E iv 1, folios 51-52, P. Walsh has the entry: Aodh Ruadh m Philip m. Aodh[a] do marbhadh re Gallaib 1651; see C. O Lochlainn (ed.), Irish chiefs and leaders: studies by Paul Walsh, 145, entry 28. 
10(9)r10. Maolmorrda mac Pilib mhic Maolmorrdha] One 'Mulmore mc Phillip Ó Rely of Trinity Iland gent' was accused of rebellion, robbery and cruelty by witness 115: see Cavan Depositions, see A. Clarke et al. (eds), 1641 Depositions, ii, $115=$ TCD MS 832, fol. 36r; this index is apparently not available online. Walsh has: Maolmórrdha m Pilip m Maolmórrdha do marbhadh 1649; see 'Notes on the O'Reilly Family' in C. O Lochlainn (ed.), Irish chiefs and leaders: studies by Paul Walsh, 145, entry 29.

10(9)r11. Maolmordha mac Cathaoír mic Seaain] This is Maol Mórdha son of Cathair son of Seán son of Toirrdhealbhach son of Fearghal Ó Raghallaigh: see, Carney, A genealogical history of the O'Reillys, § 17 (pp. 40-41). Walsh cites: Maolmórrdha m. Cathaoir m. Seáin do marbhadh 1649; see 'Notes on the O'Reilly Family', 145, entry 34. See also Mulmore Mc Cahir McShane O Rely in Cavan Deposition 402 (Richard Parsons, Drung and Laragh, 24 February 1645); see Clarke et al., 1641 Depositions, ii, 350 = TCD MS 833, fol. 280r; not yet available online.

10(9)r12. Maol Morrdha mac Seaain Séadhach na] A genealogical history of the O’Reillys has: Maol Mórdha son of Seán na Seach son of Brian son of Fearghal Óg; see $\S 20$ (p. 44).

10(9)r. Toirrdhealbhach mac Cathaoir mhic Eoghuin] This person may be one and the same person as Toirrdhealbhach son of Cathal son of Eoghan Ruadh Ó Raghallaigh who is listed as a son of Domhnall Ballach in Carney, A genealogical history of the O'Reillys, § 29 (p. 55). In the Depositions he appears as 'Turlough mc Cahir Ó Rely of Ballinecarge'; see, for example, Cavan Deposition 61 (See 1641 Depositions, ii, 73 = TCD MS 832, fol. 80r; online at http://1641.tcd.ie/deposition. php?depID=832080r061; Marmaduke Bateman, Ballyhaise, 13 April 1643); see also the 'Articles of Agreement concluded and agreed upon, the quarter given by Hugh Mac Shan Rely, and the rest of the gentlemen here under named to Sir Francis Hamilton', 4 June 1642 in which 'Tirlagh, [sic] Cahil Relie' is named: see Gilbert, Contemporary history, i, Part 2 (Dublin, 1879), 494-95.

10(9)r14. Sémus mac Tomáis mic Semhuis Bhuidhe] This may be Sémus Óg son of Tomás son of Sémus Bán Ó Raghallaigh; see Carney, A genealogical history of the O'Reillys, § 26.

10(9)r15. Séan Óg O Raghallaigh] This person may be identifiable in the Depositions as 'Shane oge McOwen McTarlach' of Lios Clochair: see Cavan Deposition 324 ('List of Rebels', 1641 Depositions, ii, 252-53 = TCD MS 833, fol. 162r; not yet available online) or as Captain 'Shane oge mc Conor Rellie of Balaghane'; see Cavan Deposition 319 (1641 Deposition, ii, 247 = TCD MS 833, fol. 153v; Francis Graham, Drumgoon, 2 November 1642). He is listed as a captain of his own company after the name 'Shane Oge OReilly' in a regiment commanded by 'Colonel Phillip McHugh O'Reilly' at Clonmel; see 'Muster of Ulster horse and foot at Clonmel, January 1649-50': Gilbert, Contemporary history, ii, Part 2 (Dublin, 1880), 503. 
10(9)r15. Semus mac Conchabhuir] This figure appears as 'Captain James McKnogher o Rely' in Cavan Deposition 376 (1641 Depositions, i, 304 = TCD MS 833, fol. 230v; not yet available online; George Creighton, 15 April 1643).

10(9)r16. mac Sé ain mhic Aódha] This entry and the one above should perhaps be taken together to read: Semus mac Conchabhair mic Seáin mhic Aodha [Uí Raghallaigh] or Séamus mac Seáin mhic Aodha mhic Conchubhair.

10(9)r16. Toirrdhealbhach mhac Cathain $\mathbf{m} \boldsymbol{h i c}$ Aodha] This name could be read as Toirrdhealbhach mhac Cathair/Cathail mhic Aodha.

10(9)r17. Pilib Ó Gabann] 'Phillip Ó Gowne of the parish of Lawie' was accused of robbery by witness 60; 'Phillip Ó Gowen of Corfad yeoman' was also accused of robbery and cruelty by witness 78: see 1641 Depositions, ii, 22-23 = TCD MS 832, fols, 15v, 16r; not available online.

10(9)r17. Eogan Ó Gabhann] 'Owen o Gowen' is mentioned in Cavan Deposition 271 (Deposition of Ellen Ward, Portmoylin, 24 January 1642). 'Owen mc Gowen of the parish of kildrumfert yeoman' was accused of robbery: see 1641 Depositions, ii, 21 = TCD MS 832, fol. 15r; not yet available online.

10(9)r18. Toirrdhealbhach Óg O Boíghil mac Toirrdhealbhaigh] A LieutenantColonel called 'Terlough OBoyle' appears on a list of the officers killed or taken prisoner on the 21 June 'at the field of Scarfollis near Litterkenny'. For the list, see 'Military operations in Ulster. - Sir Charles Coote to Henry Ireton, Lord Deputy in Ireland' in Gilbert, Contemporary history, iii, Part 1, Appendix, 150.

\section{Index of places and population groups}

Alba, Scotland, 7r19, 7r21.

Albanach, Scotsman, 9(8)r18.

An tSúileach, see tSúileach, An.

Áth Cliath, Dublin, 7r7.

Baile an Aird, Ballinard, 7r13.

Baile Shoilian, Julianstown, Co. Meath, 6v 19.

Bheinn Bhoirb, [An], Benburb, Co. Tyrone, 9(8)r6.

Bréifne, a territory that corresponds approximately to the diocese of Kilmore; Iarthar Bhréifne (W. Breifne) was controlled by the O'Rourkes and the Mac Clanceys while Oirthear Bhréifne was controlled by the O'Reillys, the McGoverns and the Bradys) 6v20.

Bun Doroige, Bunderaga, Co. Antrim, 7v11.

Caiseal Mumhan, Cashel, Co. Tipperary, 7r15.

Cenél Fhairtigh, [ = Ceinél Faghartaigh] of the Barony of Kinelarty, in S. Down, $7 \mathrm{v} 16$.

Clochar, [An], the diocese of Clogher, 9(8)v. 
Cluain Éis, Clones, Co. Monaghan, 9(8)r4.

Cluain Meala, Clonmel, Co. Tipperary, $7 \mathrm{r} 18$.

Cluain na nGall, Clonegal(1), Co. Carlow, 7r5.

Cnoc na nDos, Knocknanuss, Co. Cork, 7r19.

Connacht, 7r24, 7v6.

Cros Riabhaigh, (= Lios Riabhach/Lisrevagh, Parish of Rathcline, Barony of Rathcline, Co. Longford ?), 7v4.

Dealbhna, Delvin, Co. Westmeath, $7 \mathrm{r} 3$.

Droichead Teach Mo-Laga, see Tigh Mo-Laga, 7r14.

Droim Fliuch, alternative name for location of battle of Benburb, 9(8)r6-7.

Droim Lighean, Drumleene, Parish of Clonleigh, Barony of Raphoe, Co. Donegal, 9 (8)r12.

Éire, Ireland, 6v4, 7v17, et passim.

Éireannach, Irishman, 6v12-13, 6v17, 6v22, 7r15, et passim.

Fir Alban, the Scots, 7r21.

Fir Bhréifne, the men of Bréifne, 6v20.

Fir Éireann, the Irish, 7r21.

Fir Saxan, the men of England, 9(8)r16.

Gaillimh, Galway [City], 7v7.

Gaoidhil, Irishmen and their brethren from the Scottish Gaeltacht, 6v5, 7r22.

Gleann Cuind, Glenmaquin, Co. Donegal, 7v14.

Goill, Foreigners, the English, 6v4, 9(8)r7.

In(n)is Ceileann, Enniskillen, Co. Fermanagh, 9(8)r10, 9(8)r22, 9(8)v5, 9(8)v7.

In(n)is Scceilleinn, see In(n)is Ceileann.

In(n)is Uí Chuinn, Barony of Inchiquin, Co. Clare, 7r15.

Iubhar Chinn Trágha, Newry, Co. Down, 7v20.

Leitir cCeannuinn, Letterkenny, Co. Donegal, 9(8)r13-14.

Lios Cearbhaill, Liscaroll, Barony of Orrery and Kilmore, Co. Cork, 7r12.

Lios na gCearbhach, Lisburn/Lisnagarvey, Cos. Antrim/Down, 7v13.

Lios na Srian, Lisnastrean, Parish of Drumbeg, Barony of Castlereagh Upper, Co. Down, 9(8)r11.

Loch Garman, Wexford, 7r8, 7r9.

Lundain, London, 9(8)v6.

Maigh Fionncha, Finnea, Co. Longford, 7v8.

Mainistir Fhear Muighe, Fermoy, Co. Cork, 7r11.

Midhe, county of Meath, 6v17.

Mullach Masden, Mullagmast, 7r1.

Mumhain, Munster, 7 r10.

Oileán Mhéig Aoidh (Oileán Mhég Gaoth), Island Magee, Co. Antrim, 7v19.

Páirc in Bhloinnse, Blanchville Park, Co. Kilkenny, $7 \mathrm{r6}$.

Ros Comáin, Roscommon [Town], 7v2, 7v3.

Saxan, England, 9(8)r16.

Saxanach, Englishman, 6v19, 7r11, 9(8)r12. 
Sbáinn, Spain, 6v11.

Sliabh cCuilinn, Slieve Gullion, Co. Armagh, 9(8)r3.

Sliabh Roisil, Slieve Russell mountain, counties Fermanagh and Cavan, 7v9.

Sliabh an Tuirc, Slievetuirk, near Newport, Co. Mayo, 7v1.

Sligeach, Sligo, 7v5.

Tigh Mo-Laige, Timoleague, Barony of Ibane and Barryroe, Co. Cork, 7r14.

Tigh Mo-Ling, Timoline, S. Kildare, 7r4.

Tigh Mo-Linn, see Tigh Mo-Ling above.

Tulach Álainn, near Mellifont, Barony of Ferrard, Co. Louth, 6v22.

Uladh, Ulster, 7v10, 9(8)r5, 9 (8)r 7, 9 (8)r15.

tSúileach, An, The Swilly, Co. Donegal, 9(8)r13.

\section{Index of personal names}

Easpag (Easbog) an Chlochair, 9[8]v7.

Mac Domhnaill, Alasdron (Alasdar) mac Colla Ciotaigh, 7r20-21, 7v11-12, 7v14-15.

Mac Mathghamhna, Aodh Óg mac Briain mic Aodha Óig mic Aodha mic Sheaáin Buidhe, Tighearna Oirghiall, 9(8)v9-10.

Mac Mathghamhna, Aodh mac Airt Óig [= Aodh mac Airt Ruaidh (?)], 10(9)r1.

Mac Mathghamhna, Aodh Óg mac Colla mhic Bhriain mhic Éibhir, 10(9)r4.

Mac Mathghamhna, Art mac Rughraidh mhic Giolla Pádraig, 10(9)r2.

Mac Mathghamhna, Pádraig mac Eoghain mhic Rughraidh of Baile Lios na Somán, Barony of Dartrey, 10(9)r3.

Mac Mathghamhna, Pádraig mac Éibhear mhic Bhriain, 10[9]r5.

Mac Mathghamhna, Éibhear, Easbog an Chlochair, 9[8]v7.

Mág Uidhir, [Aodh] mac Bhriain, 9(8)v23.

Mág Uidhir, Conchubhar mac Briain mhic Conchubhair, Tighearna Inis Ceillionn, 9(8)v5-6.

Mág Uidhir, Rughraidh, 9(8)v21.

Ó Baoighill, Toirrdhealbhach Óg mac Toirrdhealbhaigh, 10(9)r18.

Ó Catháin, Maghnus Ruadh mac Séamuis Mhic Gofraidh, 9(8)v20-21.

Ó Catháin, Sémus mac Gofraidh, 9[8]v17.

Ó Domhnaill, Aodh Buidhe mac Toirdhealbhaigh mhic Cathbhairr, 9(8)v16.

Ó Domhnaill, Maghnus mac Néill Gairbh, 9(8)v15.

Ó Gabhann, Eoghan, 10(9)r17.

Ó Gabhann, Pilib, 10(9)r17.

Ó Néill, Art Óg mac Toirdhealbhaigh mhic Énrí na nGarrthan mhic Féidhlim Ruaidh of Tullaigh Dhomhnaill in the Fews, 9(8)v13.

Ó Néill, Art mac Cuinn mhic Seaáin an Díomuis, 9(8)v12.

Ó Néill, Conn Óg mac Cuinn mhic Néill mhic Briain Fhogartaigh mhic Néill Óig mhic Néill Mhóir of Clann Aodha Buidhe, 9(8)v10.

Ó Néill, Eoghan Ruadh, 9(8)r4-5, 9(8)r7. 
Ó Néill, Feidhlim mac Tuathail mhic Néill mhic Briain Fogartaigh of Clann Aodha Buidhe, 9(8)v11.

Ó Néill, Sior Féidhlim Ruadh mhic Thoirrdhealbhaigh Óig mhic Énrí Óig mhic Énrí mhic Sheáin of Ceann Ard, 9(8)r23, 9(8)v3-4.

Ó Néill, Toirrdhealbach mac Bhriain mhic Énrí Óig of Muintir Birn agus Tuath Threana 9[8]v14.

Ó Raghallaigh, [Aodh Ruadh ?] mac Sheáin mhic Aodha, 10(9)r16 (?).

Ó Raghallaigh, Aodh Ruadh mac Pilib mhic Aodha mhic Sheaáin mhic Aodha Conallaigh, 10(9)r9.

Ó Raghallaigh, Eoghan mac Seaáin mhic Philib Óig, 10(9)r8.

Ó Raghallaigh, mac Aoidh.

Ó Raghallaigh, Maol Mórdha mac Cathaoir mhic Sheaáin mhic Aodha Conallaigh of Cornegall, 10(9)r11.

Ó Raghallaigh, Maol Mórdha mac Pilib mhic Mhaoil Mhórdha mhic Éamoinn Riabhaigh, 10(9)r10.

Ó Raghallaigh, Maol Mórdha mac Sheaáin Séadaigh mhic ..., 10(9)r12.

Ó Raghallaigh, Pilib [Ruadh] mac Aoidh mhic Sheaáin Ruaidh, 6v19-20.

Ó Raghallaigh, Sémus mac Conchubhair mhic Sheaáin, 10(9)r15-16.

Ó Raghallaigh, Sémus Óg mac Tomáis mhic Sémuis Bhuidhe, 10(9)r14.

Ó Raghallaigh, Séan Óg, 10(9)r15.

Ó Raghallaigh, Toirrdhealbhach mac Cathail mhic Aodha, 10(9)r16-17.

Ó Raghallaigh, Toirrdhealbhach mac Cathaoir mhic Eoghain, 10(9)r13.

Ua Néill, see Ó Néill. 